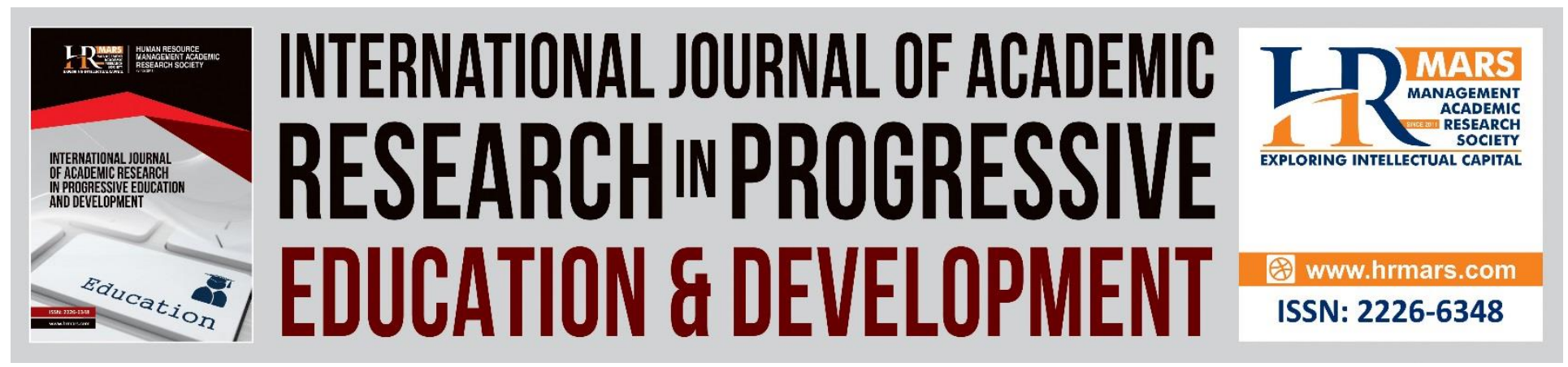

\title{
Developing and Validating a Strategic Plan for Gifted Education in Private Primary Schools
}

\section{Hussein Salem Mubarak Barabwd, Mohammad Yusoff Bin Mohd Nor, Abu Yazid Abu Bakar}

To Link this Article: http://dx.doi.org/10.6007/IJARPED/v9-i3/8171

DOI:10.6007/IJARPED/v9-i3/8171

Received: 04 August 2020, Revised: 23 August 2020, Accepted: 14 September 2020

Published Online: 27 October 2020

In-Text Citation: (Barabwd et al., 2020)

To Cite this Article: Barabwd, H. S. M., Nor, M. Y. B. M., \& Bakar, A. Y. A. (2020). Developing and Validating a Strategic Plan for Gifted Education in Private Primary Schools. International Journal of Academic Research in Business and Social Sciences, 9(3), 184-212.

Copyright: (C) 2020 The Author(s)

Published by Human Resource Management Academic Research Society (www.hrmars.com)

This article is published under the Creative Commons Attribution (CC BY 4.0) license. Anyone may reproduce, distribute, translate and create derivative works of this article (for both commercial and non-commercial purposes), subject to full attribution to the original publication and authors. The full terms of this license may be seen at: http://creativecommons.org/licences/by/4.0/legalcode

\section{Vol. 9(3) 2020, Pg. 184 - 212}

Full Terms \& Conditions of access and use can be found at http://hrmars.com/index.php/pages/detail/publication-ethics 


\title{
LRE INTERNATIONAL JOURNAL OF ACADEMIC RESEARCHINPROGRESSIVE EDUCATION \& DEVELOPMENT \\ Developing and Validating a Strategic Plan for Gifted Education in Private Primary Schools
}

\section{Hussein Salem Mubarak Barabwd, Mohammad Yusoff Bin Mohd Nor, Abu Yazid Abu Bakar}

Faculty of Education, Universiti Kebangsaan Malaysia, Bangi, Selangor, Malaysia

Email: barabwd@gmail.com

\begin{abstract}
Gifted education, defined as the schooling of students demonstrating some exceptional abilities, is relatively new in the Republic of Yemen; hence, it has been started in 2005 in five government schools located in three governorates. Therefore, this study aims to propose a strategic plan for developing gifted education in Private Primary Schools (PPS) in Hadhramout governorate; and to generate a consensus among experts on the proposed strategy. The study employed a mixed quantitative/qualitative approach and was conducted in two phases: qualitative and quantitative. In the first phase, data were collected through focus groups. While, in phase two, data were collected through questionnaires using the Fuzzy Delphi Method. A total of 9 private primary school principals and 23 experts in several specialisations were involved in this study. The results revealed that the proposed strategic plan contained seven domains covered 51 items. The seven items are Identification of Gifted Students IGS, Syllabus Materials for Gifted Students SMGS, Staff Development in Gifted Education SDGE, Assessment of Gifted Students Performance AGSP, Assessment of Services of Gifted Students ASGS, Strategic Planning for gifted Education SPGE and Implementation Policy for Gifted Education IPGE. Finally, the study recommended PPS to prioritise staff development to implement this strategy.
\end{abstract}

Keywords: Gifted Education, Strategic Plan, Primary Schools

\section{Introduction}

The term "strategy" comes from two Greek words: "Stratos", which means "army", and "again" which means "leading" - namely, "army-leading" (Ambrosi, 2010; Merriam \& Tisdell, 2015). However, the term strategy is used not only in the military domain but also in various fields of life. Therefore, there are several definitions of the term strategic plan; for instance, Alfred (2006) defined it as "the systematic way of positioning an institution with stakeholders in its environment to create value that differentiates it from competitors and leads to a sustainable advantage" (p. 6). Also, Mittenthal (2002) defined it as "a tool that guides in fulfilling a mission with maximum efficiency and impact if it is to be effective and useful, it should articulate specific goals and describe the action steps and resources needed to accomplish them". According to 
Johnson and Christensen (2008), the strategy is the long-term direction and scope of an organisation that accomplish a benefit in changing the goal of achieving stakeholder's expectations. Based on theoretical views, there are two approaches to strategy formulation: rational approach and emergent approach. The rational approach is based on the presupposition that the environment is relatively predictable and that an organisation is tightly coupled so that all decisions made at the top can be implemented throughout the organization. On the other hand, the emergent approach is based on an organisation continually responding to changes by adapting, in a very similar way, to how living organisms respond to their environment (Kaonde, 2014). Several authors, such as (Porter, 2008), defined strategy formulation as a process through which an organisation's strategy is developed. It comprises defining the corporate mission, specifying achievable objectives, developing strategies and setting policy guidelines. Furthermore, identified the procedure of strategic planning processes on the basis of four steps: a) objectives establishment; b) estimation of the gap between the current position of the firm or institution and its objectives; $c$ ) the position of the strategy courses and d) testing for the ability to reduce the gap (Ambrosi 2010). The ultimate purpose of strategic planning is to set the organisation's goals and then develop a plan to accomplish them; it provides an organisation with the right step forward to achieve its goals. Similarly, in educational context, the educational institutions should formulate their strategic plans to achieve their goals (Yikici, Altinay, \& Quantity, 2018). Therefore, this study aimed to answer these two questions a) what is the proposed strategic plan for developing gifted education in private basic education schools in Hadhramout governorate? And b) what is the degree of consensus among experts on the proposed strategic plan for developing gifted education in the private basic education schools in Hadhramout governorate?

\section{Methodology}

The study employed a mixed quantitative/qualitative approach and was conducted in two phases: qualitative and quantitative. In the first phase, data were collected through focus groups. In phase two, data were collected through questionnaires using the Fuzzy Delphi Method. A total of 9 private primary school principals and 23 experts in several specialisations such as educational administration, syllabus and instruction methods and psychology were involved in this study. The researchers videoed and recorded the focus group session after obtaining permission from the participants to do so. Qualitative data were analysed using content analysis and a thematic approach using the Atlas ti. (Version 8) software programme specialised for the analysis of qualitative data.

The validity and reliability are achieved in this study by asking a group of experts to validate the focus group protocol that was prepared for the principals of the targeted schools. The ultimate aim of the validation process was to ensure that the questions were aligned to the aim of the study and obtained the required data. Two types of validity were utilised for the qualitative data namely, construct and content validity. Besides, member-checking and interrater agreement were executed in order to ensure the reliability of the data. Merriam and Tisdell (2015) reported that member checking is one of six strategies in guaranteeing the validity. For member checking (otherwise respondent validation), the researchers verified and validated the transcribed data. Once they found any disagreement with the transcription, they could make any 
amendments. Besides, a copy of the transcription document was emailed to the respondents, each of whom was allowed to clarify any doubts or make any necessary amendments on the transcription. The participants explained their satisfaction with the transcription, thereby leading to the inter-rater agreement.

\section{Focus Group Data Analysis}

The thematic approach was employed to analyse the qualitative data gathered from the focus group. The researchers familiarised themselves with the for the sake of getting an overall idea of how the data could have interfered. Merriam and Tisdell (2015) argued that the transcript should be prepared in a verbatim form that is the best data platform for analysing process. While listening to the recordings several times, simultaneously browsing through the transcription to countercheck the written transcriptions. Seven domains cover 51 items were collated from focus group findings. Then they were recorded in the form of a questionnaire.

\section{Fuzzy Delphi Method Analysis}

In the beginning, the experts were asked to respond to the items on the proposed strategic plan using a five-point Likert scale (strongly agree, agree, neutral, disagree, and strongly disagree). Every individual scale was represented by a particular rubric that provided some guidelines to the experts in assigning the scale to choose. For instance, strongly agree would reflect the most related point and strongly disagree with the least relevant point. First-order priority and very important has a direct bearing on major issues besides must be resolved, dealt with or treated. The rubric covers till the lowest linguistic scale. This scale represents no priority and irrelevance, most unimportant, no measurable effect and should be dropped as an item to consider. Fuzzy Delphi method was established to solve the problem of the traditional Delphi method (Mohamad, Embi, \& Nordin, 2015) that is usually used for implementing accurate group consensus decisions (Bin Suliman, 2020). There are five steps to conduct the Fuzzy Delphi technique. Firstly, determining the experts; secondly, choosing a linguistic scale; thirdly, identifying the average value; fourthly, determining the value of " $d$ " (threshold value). The threshold value is significant to achieving at least (d) $\leq 0.2$ or it accedes 75 per cent consensus. Chu and Hwang (2008) Murry Jr and Hammons (1995) argued that if the consensus percentage was similar to or greater than $75 \%$, then the group consensus had been fulfilled. At this stage, the ranking of items was determined; fifthly, the diffusified process occurred. Therefore, the researcher needed to key the data into software whether SPSS or even excel in order to run the analysis as the Fuzzy Delphi method which was required to generate the consensus value. These are the steps of Fuzzy Delphi analysis as stated in (Mohamad et al., 2015):

i. Assume that $(K)$ experts are invited to determine the proposed strategic plan and practice policy, and the ratings of alternatives with respect to various criteria using variables table.

ii. Convert the variables into triangular fuzzy numbers as suggested in table 1. Make the Fuzzy numbers be the rating of alternative (i) with respect to criteria and be the (jth) criteria weight of the (kth) expert for $\mathrm{i}=1, \ldots . \mathrm{m}, \mathrm{j}=1, \ldots, \mathrm{n}, \mathrm{k}=1, \ldots, \mathrm{k}=1, \ldots, \mathrm{K}$. ad $\mathrm{r}_{i j} \equiv \frac{1}{k}\left( \pm \mathrm{r}_{i j} \mathrm{r}_{2 i j} \pm \mathrm{r}_{k i j}\right)$ 
Vol. 9, No. 3, 2020, E-ISSN: $2226-6348$ @ 2020 HRMARS

Table: 1 Fuzzy Delphi Scale for the Items

\begin{tabular}{|l|l|}
\hline Items & Fuzzy Scale \\
\hline Strongly disagree & $(0.0,0.1,0.2)$ \\
\hline Disagree & $(0.1,0.2,0.4)$ \\
\hline Moderately agree & $(0.2,0.4,0.6)$ \\
\hline Agree & $(0.4,0.6,0.8)$ \\
\hline Strongly agree & $(0.6,0.8,1.0)$ \\
\hline
\end{tabular}

Source: (Mohamad et al., 2015)

iii.For each expert, use the vertex method to compute the distance between the average $\sim$ rij and $\mathrm{r}_{i j}$ and the distance between the average $\omega_{i j}$ and $\widetilde{\omega}_{j}^{k}, \mathrm{k}=, \mathrm{K}$ (Chen \& systems, 2000). The distance between two Fuzzy numbers $\tilde{m}=(m 1, m 2, m 3)$ and $\tilde{n}=(n 1, n 2, n 3)$ is computed by:

$$
d(\tilde{m} \tilde{n})=\sqrt{\frac{1}{k}}[(m 1-n 1) 2+(m 2-n 2) 2+(m 3-n 3) 2]
$$

If the distance between the average and experts assessment data is less than the threshold value of 0.2 , then all experts are considered to have achieved a consensus (Cheng \& Lin, 2002). Also, among those $m \times n$ ratings of alternatives and $\mathrm{n}$ criteria weights, if the percentage of achieving a group consensus is greater than $75 \%$, then proceed to step four or otherwise, the second round of survey is required.

iv. Aggregate the Fuzzy assessment by:

$$
\begin{aligned}
& A\left|\begin{array}{c}
\widetilde{A 1} \\
\widetilde{A 2} \\
\vdots \\
\widetilde{A m}
\end{array}\right| \text { where } A \widetilde{\mathrm{Ar}_{l 1}} X \mathrm{w}_{1}+\mathrm{r}_{l 2} X \mathrm{w}_{2}+\cdots \cdots \cdots \mathrm{wr}_{l n} X \mathrm{w}_{l n} \\
& i=1,2, \cdots \cdots, m
\end{aligned}
$$

v. For each alternative option, the Fuzzy assessment:

a. $\quad \tilde{A}=($ ai1 1 ai2, ai3 $)$ is defuzzified by:

$$
\tilde{A}=\frac{1}{4} a i 1+2 a i 2+2 a i 3
$$

The ranking order of alternative options can be determined according to the values of $a i$ (Mohamad et al., 2015).

The software determines the consensus level among the experts as well as proving the ranking of items. also, the experts' consensus would assign which of the items of the strategic plan highly impede gifted education implementation, and which goals, objectives and strategies are the most feasible to conduct. Therefore, it would be advantageous to the researchers to obtain approval for the proposed strategic plan for gifted education in PPS in Hadhramout governorate (Bin Suliman, 2020; Darwish et al., 2020).

\section{Results}

The results were showed in tow phases, phase one, answers the question number one of this study. It presents the focus group findings including the themes of the proposed strategic plan for gifted education. While phase two answers question number two that presents the Fuzzy 
Delphi method results that cover the experts' consensus on the themes of the proposed strategic plan.

\section{Phase One Results}

The results revealed that the proposed strategic plan contained seven domains namely: Identification of Gifted Students (IGS), Syllabus Materials for Gifted Students (SMGS), Staff Development for Gifted Education (SDGE), Assessment of Gifted Students Performance (AGSP), Assessment of the Services of Gifted Students (ASGS), Strategic Plan for Gifted Education (SPGE), and Implementation policy for gifted education (IPGE). Every domain covered several themes as shown in the next sub-sections.

\section{Themes for Identification of Gifted Students (IGS)}

The following table shows the codes, categories, and themes for IGS, that the participants considered one of the most important elements in gifted education. This focused on several significant ideas generated by the participants.

Table: 2 Themes for IGS

\begin{tabular}{|c|c|c|c|}
\hline No. & Codes & Categories & Themes \\
\hline 1. & $\begin{array}{l}\text { Differentiate giftedness } \\
\text { concepts }\end{array}$ & $\begin{array}{l}\text { Giftedness } \\
\text { concepts }\end{array}$ & $\begin{array}{l}\text { Define operationally the giftedness } \\
\text { concepts for the schools. }\end{array}$ \\
\hline 2. & $\begin{array}{l}\text { Provide identification } \\
\text { tools }\end{array}$ & $\begin{array}{l}\text { Identification } \\
\text { tools }\end{array}$ & $\begin{array}{l}\text { Provide multiple types of identification } \\
\text { tools. }\end{array}$ \\
\hline 3. & Setting an ideology & Ideology & $\begin{array}{l}\text { Determine an inclusive approach for the } \\
\text { identification of the gifted. }\end{array}$ \\
\hline 4. & $\begin{array}{l}\text { Specify procedures of } \\
\text { identification }\end{array}$ & $\begin{array}{l}\text { Identification } \\
\text { procedures }\end{array}$ & Determine identification procedures. \\
\hline 5. & Training the school staff & Training & $\begin{array}{l}\text { Training school staff in the identification of } \\
\text { the gifted. }\end{array}$ \\
\hline
\end{tabular}

The findings revealed that the participants were very curious about the process of identification of gifted students. As a consequence, the first factor they mentioned was the operational definition of giftedness. They argued that once the giftedness concept is defined clearly, it will be helpful in recognising gifted students. This also was confirmed by some scholars such as (Faulkner, 2003; Plucker \& Barab, 2005; VanTassel-Baska, 2009a).

In this context, respondent $\mathrm{H}$. A affirmed that:

"...also we should differentiate between different concepts that relate to giftedness; for example, the gifted, talented, and creative, all these concepts which seem to be similar but they are not. Thus, there must be a clear definition of who is gifted in our schools".

After defining the concept of giftedness, the need for useful tools to identify those who are gifted appears. Therefore, the participants confirmed the importance of the tools for identifying gifted students such as intelligence tests. For instance, respondent F.Q stated, "...also the presence of the identification tools such as the intelligence tests is necessary".

Also, one significant factor is the lack of a model for gifted education in the PPS, whether this is for identifying or catering for gifted students. They, therefore, require an inclusive approach to 
the identification of gifted students. Here is what the respondent F.B stated in this regard: "...the priorities of identifying those who are gifted; firstly, setting a methodology and training the school staff in it".

Indeed, training staff in the identification of the gifted is considered one of the significant requirements for developing gifted education in PPS. If the teachers are not able to identify gifted students such students may drop out of school or become bored with school. For instance, respondent F.Q claimed "...each school should train a team from its staff on the methods for identifying the gifted students. Because staff with no training on this issue will not be able to identify the gifted students and it will be difficult for them".

\section{Themes of Syllabus Materials for Gifted Students (SMGS)}

The syllabus materials are not important for gifted students only but also very important for the teachers. Because if they do not have enrichment materials for those who are exceptional students they will find nothing to provide for them. Therefore, this is a proposed strategic plan for developing syllabus materials for gifted students that were build based on participants' views. Table 3 shows the themes for SMGS.

Table: 3 Themes for SMGS

\begin{tabular}{|c|c|c|c|}
\hline No. & Codes & Categories & Themes \\
\hline 1. & $\begin{array}{l}\text { Enrichment materials } \\
\text { for gifted }\end{array}$ & $\begin{array}{l}\text { Enrichment } \\
\text { materials }\end{array}$ & $\begin{array}{l}\text { Adding additional enrichment materials for } \\
\text { gifted students. }\end{array}$ \\
\hline 2. & The official syllabus & Syllabus & $\begin{array}{l}\text { The schools can employ an official syllabus for } \\
\text { the gifted by applying their extracurricular } \\
\text { activities. }\end{array}$ \\
\hline 3. & $\begin{array}{l}\text { Enrichment } \\
\text { programmes }\end{array}$ & $\begin{array}{l}\text { Enrichment } \\
\text { programmes }\end{array}$ & $\begin{array}{l}\text { The schools should develop enrichment } \\
\text { programmes for gifted students. }\end{array}$ \\
\hline 4. & $\begin{array}{l}\text { Analysing the official } \\
\text { syllabus }\end{array}$ & $\begin{array}{l}\text { Official } \\
\text { syllabus }\end{array}$ & $\begin{array}{l}\text { Analysing the official syllabus to determine how } \\
\text { to employ extracurricular activities for the } \\
\text { gifted students. }\end{array}$ \\
\hline 5. & $\begin{array}{l}\text { Developing a gifted } \\
\text { syllabus }\end{array}$ & $\begin{array}{l}\text { Gifted } \\
\text { syllabus }\end{array}$ & $\begin{array}{l}\text { Schools alone cannot develop a syllabus for } \\
\text { gifted students, it is not their task. }\end{array}$ \\
\hline
\end{tabular}

As a strategy for solving the lack of syllabus materials for gifted students, the participants suggested that PPS can add some additional syllabus materials specially developed for gifted students. They argued that the official syllabus is not sufficient to meet the multiple needs of gifted students. For instance, participant F.B stated that:

"... what can develop our gifted students, either the official syllabus or by adding some subject materials to it as an enrichment syllabus? So I think we can archive our goals from the same official syllabus or by adding some subjects as mentioned earlier".

However, some of the participants thought that the official syllabus can be employed to meet gifted students' needs once they apply all its activities. For example, respondent A.B claimed that: "...the process of designing a syllabus is not the school's role. But we can say that the school's role is to activate the standard syllabus by applying extracurricular activities. Our syllabus is full of practical activities; if they are taught to the students that will enable them to develop their 
Vol. 9, No. 3, 2020, E-ISSN: $2226-6348$ @ 2020 HRMARS

thinking skills, abilities, and giftedness as well. Furthermore, the teacher can employ any topic for the gifted students in his class".

\section{Themes of Staff Development in Gifted Education (SDGE)}

The participants counted staff development one of the most significant factors in gifted education. They required inclusive training for the PPS staffs in all domains of gifted education. The following table shows the themes for SDGE.

Table: 4 Themes for SDGE

\begin{tabular}{|c|c|c|c|}
\hline No. & Codes & Categories & Themes \\
\hline 1. & $\begin{array}{l}\text { Training the staff on the } \\
\text { identification }\end{array}$ & Staff training & $\begin{array}{l}\text { Train the staff in the identification of gifted } \\
\text { students. }\end{array}$ \\
\hline 2. & Training the staff & The staff & $\begin{array}{l}\text { Train the staff in multiple gifted education } \\
\text { issues. }\end{array}$ \\
\hline 3. & $\begin{array}{l}\text { The awareness of gifted } \\
\text { education }\end{array}$ & $\begin{array}{l}\text { Staff } \\
\text { awareness }\end{array}$ & Raising staff awareness of gifted education. \\
\hline 4. & $\begin{array}{l}\text { Gifted committee of } \\
\text { teachers }\end{array}$ & $\begin{array}{l}\text { Set up a } \\
\text { school } \\
\text { committee }\end{array}$ & $\begin{array}{l}\text { Develop a committee of teachers for gifted } \\
\text { education. }\end{array}$ \\
\hline 5. & $\begin{array}{l}\text { The policy of } \\
\text { employment and training }\end{array}$ & $\begin{array}{l}\text { Employment } \\
\text { policy }\end{array}$ & $\begin{array}{l}\text { Develop an employment policy for newly } \\
\text { qualified teachers. }\end{array}$ \\
\hline 6. & $\begin{array}{l}\text { A teacher of gifted } \\
\text { students in every school }\end{array}$ & Teachers & $\begin{array}{l}\text { Specify certain teachers as gifted education } \\
\text { teachers. }\end{array}$ \\
\hline
\end{tabular}

Participants confirmed that training the staff enhances their performance in gifted education. For example, respondent F.B emphasised that "...it is crucial to ensure the staff are qualified and to choose a good teacher who is able and enthusiastic towards helping the gifted".

In the same context, respondent M.A explained that "...to develop our staff we need policies or rules in our schools so that we know who is suitable for working with the gifted".

The participants mentioned several issues that they need to train the staffs on them. For example, M.A suggested the following ideas for training the school staff:

"...then develop them for example by sending them to field visits to see the best schools and to learn from the experiences of other schools. A real example; why not take the participants in this focus group to Malaysia to take a course or workshop on how to identify the gifted. Also from the priorities, the provision of local and international workshops about gifted education".

\section{Themes of Assessment of Gifted Students Performance (AGSP)}

The participants clarified that there is no clear policy or even practical tools to assess students' performance in different fields of giftedness. Therefore, as school principals, we face several difficulties in this regard. The following table presents the codes, categories, and themes for AGSP. 
DEVELOPMENT

Vol. 9, No. 3, 2020, E-ISSN: $2226-6348$ @ 2020 HRMARS

Table: 5 Themes for AGSP

\begin{tabular}{|c|c|c|c|}
\hline No. & Codes & Categories & Themes \\
\hline 1. & Assessment policy & $\begin{array}{l}\text { Assessment } \\
\text { policy }\end{array}$ & $\begin{array}{l}\text { Develop a policy for the assessment of gifted } \\
\text { students' performance. }\end{array}$ \\
\hline 2. & $\begin{array}{l}\text { The provision of } \\
\text { assessment tools }\end{array}$ & $\begin{array}{l}\text { Assessment } \\
\text { tools }\end{array}$ & $\begin{array}{l}\text { Provide tools for the assessment of gifted students' } \\
\text { performance. }\end{array}$ \\
\hline 3. & Assessment stages & $\begin{array}{l}\text { Assessment } \\
\text { stages }\end{array}$ & $\begin{array}{l}\text { Following the three stages of assessment (pre, } \\
\text { during, and after). }\end{array}$ \\
\hline 4. & Specialised evaluators & $\begin{array}{l}\text { Specialised } \\
\text { evaluators }\end{array}$ & $\begin{array}{l}\text { Assessment should be conducted by specialised } \\
\text { evaluators. }\end{array}$ \\
\hline 5. & Self-assessment & $\begin{array}{l}\text { Self- } \\
\text { assessment }\end{array}$ & $\begin{array}{l}\text { Share the process of assessment with the gifted } \\
\text { students. }\end{array}$ \\
\hline 6. & $\begin{array}{l}\text { Assessment } \\
\text { championships }\end{array}$ & $\begin{array}{l}\text { Championship } \\
\text { assessment }\end{array}$ & $\begin{array}{l}\text { Championship results can be a measurement tool } \\
\text { for assessing gifted students' performance. }\end{array}$ \\
\hline
\end{tabular}

As table 5 shows that there is no policy for assessing gifted students' performance also there is a lack of tools that can be used for assessment. For instance, respondent M.A stated that:

"...if the policies are not available and there are no criteria we cannot plan. The assessment is considered an important procedure for any kind of work and it is a basic procedure. Also from the priorities, the provision of assessment tools. What is the measuring tool and what are the criteria that will be used to assess the gifted students' performance?"

Furthermore, the respondent M.A believed that those assessing the performance of gifted students should be trained specialists or qualified teachers. In this respect, M.A argued that:

"...it is important that the assessment is conducted by specialised committees; for example, in the field of Islamic singing there are different layers of the sound, these are very specific details, so the assessment committee should be specialised because not every teacher can do that."

M.A also confirmed that it is sometimes significant to allow gifted students participate in the process of assessment particularly he said that "...we hope during the assessment of the gifted students to allow them to participate with us in the process of assessment."

The participants A.B also clarified that the process of assessment is conducted through students participating in international level championships in different fields. For example, M.A participant said: "I think the schools should participate in any championship conducted by the organisations of gifted education and our goal is not only to succeed in those championships but also to determine our students' level of giftedness".

Finally, all the participants declared that the assessment process is significant as well as it is sensitive, in this context the participant F.B confirmed that:

"...the assessment factor is very crucial and sensitive at the same time because a wrong decision regarding whether a particular student is gifted or not may cause a real problem for him/her. Therefore, we need a methodology for developing criteria for the identification of the gifted, also we need clear criteria based on a scientific background that should be clear, even for the students. The assessment factor is very important, very important."

\section{Themes of Assessment Services of Gifted Students (ASGS)}

When the schools provide programmes for gifted students, they need to assess their effectiveness to determine the extent to which these programmes achieve their goals. Therefore, 
INTERNATIONAL JOURNAL OF ACADEMIC RESEARCH IN PROGRESSIVE EDUCATION AND

DEVELOPMENT

Vol. 9, No. 3, 2020, E-ISSN: $2226-6348 @ 2020$ HRMARS

the process of assessment is important as aforementioned earlier. The following table presents the codes, categories, and themes for ASGS.

Table: 6 Themes for ASGS

\begin{tabular}{|c|c|c|c|}
\hline No. & Codes & Categories & Themes \\
\hline 1. & $\begin{array}{l}\text { Assessment of gifted } \\
\text { programmes }\end{array}$ & $\begin{array}{l}\text { Gifted } \\
\text { programmes }\end{array}$ & $\begin{array}{l}\text { Assign a methodology for assessing gifted } \\
\text { services. }\end{array}$ \\
\hline 2. & $\begin{array}{l}\text { Assess the methods } \\
\text { of identification }\end{array}$ & $\begin{array}{l}\text { Methods of } \\
\text { identification }\end{array}$ & $\begin{array}{l}\text { Assess the methods for the identification of } \\
\text { gifted students. }\end{array}$ \\
\hline 3. & Tools of assessment & $\begin{array}{l}\text { Tools of } \\
\text { assessment }\end{array}$ & $\begin{array}{l}\text { Assign tools for assessing the services of gifted } \\
\text { students in the school. }\end{array}$ \\
\hline 4. & $\begin{array}{l}\text { Experienced } \\
\text { evaluators }\end{array}$ & Evaluators & $\begin{array}{l}\text { Invite specialists to assess the gifted services in } \\
\text { the school. }\end{array}$ \\
\hline 5. & $\begin{array}{l}\text { Assessment is a } \\
\text { frequent process }\end{array}$ & $\begin{array}{l}\text { Frequency of } \\
\text { assessment } \\
\text { process }\end{array}$ & $\begin{array}{l}\text { The assessment process should be conducted } \\
\text { frequently. }\end{array}$ \\
\hline
\end{tabular}

The respondents agreed on the difficulties that they face while the assessment of gifted services of programmes. That was due to the lack of practical tools or system for doing so. For example, the respondent F.B explained why this process is difficult for them. He is asking that if schools face a real problem in assessing the level of teaching and learning in general, then how they can assess the level of gifted education programmes and services in particular. His exact comment was:

"...What I want to say is that we still cannot assess the normal teaching and learning process in our schools so what about the assessment of gifted education; I think it will be more difficult for our schools to do this".

$\mathrm{He}$ also thought there was no practical system for assessing the programmes or services for gifted students, arguing that "...the assessment factor is very important. So the schools must have a frequent assessment process for the gifted service in general. For example, how do we identify gifted students? Based on what scientific theory? And how do we nominate the students? All these questions bring some obstacles."

Respondent $\mathrm{H}$. A contended that sharing the process of assessment with a specialist will help the school to assess their gifted programmes and services, stating: "...each school should involve those who are specialised in different majors of giftedness to help them assess the services or the programmes for the gifted".

\section{Themes of Strategic Plan for Gifted Education (SPGE)}

The respondents confirmed that there is a lack of strategic planning in general education as well as in special education. As a consequence, all respondents explained that their schools do not have a strategic plan for developing gifted education. Therefore, these schools need to develop their own strategic plan that develops gifted education. In this context, the following table shows the codes, categories, and themes for SPGE. 
Table: 7 Themes for SPGE

\begin{tabular}{|c|c|c|c|}
\hline No. & Codes & Categories & Themes \\
\hline 1. & $\begin{array}{l}\text { Strategic plan for gifted } \\
\text { education }\end{array}$ & $\begin{array}{l}\text { Strategic } \\
\text { planning }\end{array}$ & No strategic plan for gifted education. \\
\hline 2. & Formulate a plan & Planning & $\begin{array}{l}\text { Formulate a strategic plan to meet the } \\
\text { needs of the community and the gifted } \\
\text { students }\end{array}$ \\
\hline 3. & $\begin{array}{l}\text { Specify the strengths } \\
\text { and opportunities }\end{array}$ & $\begin{array}{l}\text { Important } \\
\text { strengths }\end{array}$ & $\begin{array}{l}\text { Planning based on strengths and } \\
\text { opportunities. }\end{array}$ \\
\hline 4. & $\begin{array}{l}\text { Specify weaknesses } \\
\text { and threats. }\end{array}$ & & $\begin{array}{l}\text { Avoiding weaknesses and threats while } \\
\text { planning. }\end{array}$ \\
\hline
\end{tabular}

As shown in the above table, one of the important findings is that the schools do not have a strategic plan to develop gifted education. However, the school principals (the respondents) recognised that it is fundamental to formulate a strategic plan in order to develop gifted education. These are some pieces of evidence from the respondents' speech, the respondent M.A tried to explain the absence of strategic planning for gifted education in schools, stating:

"... Why there is no plan for gifted education? Because there is no policy and rules for that. In the policy, the job description will be there so everything that should be conducted should be stated in the policy. For example, if one of the staff is to be responsible for the gifted segment or maybe more than one; all these issues will be stated in the policy I think".

The results reflect that there is a lack of strategic planning for gifted education in the PPS. As a consequence, the participants insisted on proposing such a plan to develop gifted education. In addition, they all agreed with participant M.B who suggested mission for the proposed strategic plan, which was "...identifying, caring, and developing gifted students using the modern methodology for the sake of developing and leading the community". He added "I think we need to add the concept "leading" because it is important".

\section{Themes of Implementation policy for gifted education (IPGE)}

The participants put priority after formulating a strategic plan is developing an implementation policy for gifted education in the PPS. The following table presents themes relating to the need for a practice policy as a strategic plan alone is not sufficient. The role of the policy is to guide the school staff during the implementation of the strategy. 


\section{Table: 8 Themes for IPGE}

\begin{tabular}{llrl}
\hline No. & Codes & Categories & Themes \\
\hline 1. & $\begin{array}{l}\text { Policy for gifted Policy } \\
\text { education }\end{array}$ & $\begin{array}{l}\text { No implementation policy for gifted } \\
\text { education }\end{array}$ \\
2. & $\begin{array}{l}\text { Standards for the Standards } \\
\text { identification of gifted } \\
\text { children }\end{array}$ & $\begin{array}{l}\text { Specify the standards for the identification } \\
\text { of gifted students. }\end{array}$ \\
Regulating for gifted Regulations \\
education
\end{tabular}

As it appears in the above table, the result shows that there is no implementation policy for gifted education in the PPS. The participants argued that the practice policy is fundamental in the gifted education field because it provides the standards and the procedures for the identification of gifted students as well as the regulations for providing equal opportunities so that all the students are involved in the suitable programmes. Therefore, the proposed strategy should lead the PPS to adopt or develop a practice policy for the sake of developing gifted education.

\section{Phase Two Results}

This phase presents the results of Fuzzy Delphi method namely the experts' consensus on the themes of the proposed strategic plan for the whole seven domains which were elucidated from the school principals through the focus group discussion and presented in the previous phase. The following sub-section presents the experts' consensus on all the proposed domains of the strategic plan for gifted education.

\section{Experts' Consensus on the Proposed Strategy for IGS}

First, experts were asked to respond to the first domain, IGS that had nine items. The following table presents the items listed under this domain. 
Table: 9 Proposed Items for IGS Domain

\begin{tabular}{lll}
\hline No. & Item Type & Items for the IGS \\
\hline 1 & Goal & Develop identification procedures for gifted students. \\
2 & Objective & Determine who the Gifted Student is"? \\
3 & Objective & Assign the standards for the identification of gifted students. \\
4 & Objective & Acquire three standard tests for the identification of gifted students. \\
5 & Objective & Assemble a trained committee for the identification of gifted students. \\
6 & Strategies & The school has to define operationally what is meant by a gifted student. \\
7 & Strategies & $\begin{array}{l}\text { The school has to list down all the adopted standards for identifying gifted } \\
\text { students. }\end{array}$ \\
8 & Strategies & $\begin{array}{l}\text { The school has to obtain at least three standard tests for identifying gifted } \\
\text { students. }\end{array}$ \\
& Strategies & The school has to train a specific committee for identifying gifted students.
\end{tabular}

To validate these items, the experts responded based on their opinions using a five-point Likert scale started from strongly agree $=5$ to strongly disagree $=1$. The result of the analysis is as follows:

Table: 10 Experts' Consensus on IGS Items

\begin{tabular}{|c|c|c|c|c|c|c|}
\hline \multirow[t]{3}{*}{ Domain } & \multirow[t]{3}{*}{ Item } & \multicolumn{3}{|l|}{ Score Value } & \multirow{3}{*}{$\begin{array}{l}\text { Response } \\
\text { Ranking }\end{array}$} & \multirow[t]{3}{*}{ Result } \\
\hline & & Fuzzy & Average Of & Element & & \\
\hline & & Assessment & Fuzzy Number & $\begin{array}{l}\text { Threshold Value } \\
\text { (D) }\end{array}$ & & \\
\hline \multirow[t]{9}{*}{ IGS } & 1 & 16.200 & 0.7364 & 0.133 & 2 & ACCEPT \\
\hline & 2 & 16.000 & 0.7273 & 0.200 & 3 & ACCEPT \\
\hline & 3 & 16.600 & 0.7545 & 0.114 & 1 & ACCEPT \\
\hline & 4 & 14.233 & 0.6470 & 0.192 & 7 & ACCEPT \\
\hline & 5 & 15.400 & 0.7000 & 0.181 & 4 & ACCEPT \\
\hline & 6 & 14.600 & 0.6636 & 0.189 & 6 & ACCEPT \\
\hline & 7 & 14.800 & 0.6727 & 0.194 & 5 & ACCEPT \\
\hline & 8 & 11.667 & 0.5303 & 0.284 & 9 & REJECT \\
\hline & 9 & 13.600 & 0.6182 & 0.232 & 8 & REJECT \\
\hline Domain & 0.191 & & & & & \\
\hline $\begin{array}{l}\text { Threshold Value } \\
\text { (d) }\end{array}$ & & & & & & \\
\hline Consensus & $78 \%$ & & & & & \\
\hline Percentage for & & & & & & \\
\hline Total Items & & & & & & \\
\hline
\end{tabular}


As depicted, the italicised threshold values were above 0.2 and therefore there was no consensus among experts. However, the total domain value (d) was less than 0.2 (0.191). This indicates that the experts have reached an overall consensus (Chang, Hsu, \& Chang, 2011; Cheng \& Lin, 2002). Also, the total percentage of the agreement fulfilled the relevant criteria as it was more than $75 \%$. The average Fuzzy response should also be more than 0.5 , as indicated by Tang and Wu (2010). In this respect, two items did not elicit a consensus among experts: The school has to operationally define what is meant by a gifted student and the school has to list down all the adopted standards for identifying gifted students. Thus, neither were major strategies for IGS according to the experts. The remaining seven items were accepted as important elements of the strategic plan for gifted education, specifically for the IGS domain.

From the above result shows that the experts believed that developing identification procedures, determining who gifted students are, assigning standards for the identification of gifted students, and assembling a trained committee for the identification of gifted students are appropriate strategies for IGS with respect to gifted education in PPS in Hadhramout governorate. Of these, the most important item is to assign standards for the identification of gifted students and the least important is assembling a trained committee for the identification of gifted students.

\section{Experts' Consensus on the Proposed Strategy for SMGS}

The second domain in the proposed strategic plan is SMGS, which contained eight items. Like the first domain, experts responded to these on a five-point Likert scale. The following table presents the items under the SMGS domain.

Table: 11 proposed Items for SMGS Domain

\begin{tabular}{|c|c|c|}
\hline No. & Item type & Items for the SMGS \\
\hline 1 & Goal & $\begin{array}{l}\text { Develop or adopt an enrichment syllabus to meet gifted students' needs } \\
\text { in multiple fields. }\end{array}$ \\
\hline 2 & Objective & Develop an enrichment syllabus in applied sciences for gifted students. \\
\hline 3 & Objective & Develop an enrichment syllabus in maths for gifted students. \\
\hline 4 & Objective & Develop an enrichment syllabus in arts for gifted students. \\
\hline 5 & Strategies & $\begin{array}{l}\text { The school has to either obtain or develop an enrichment syllabus in } \\
\text { applied sciences for gifted students. }\end{array}$ \\
\hline 6 & Strategies & $\begin{array}{l}\text { The school has to either obtain or develop an enrichment syllabus in } \\
\text { maths for gifted students. }\end{array}$ \\
\hline 7 & Strategies & $\begin{array}{l}\text { The school has to either obtain or develop an enrichment syllabus in arts } \\
\text { for gifted students. }\end{array}$ \\
\hline 8 & Strategies & $\begin{array}{l}\text { The school has to either obtain or develop an enrichment syllabus in } \\
\text { sports for gifted students. }\end{array}$ \\
\hline
\end{tabular}

The SMGS items were then sent to the experts for validation to discover their consensus on them, the results of which are as follows. 


\section{Table: 12 Experts' Consensus on SMGS Items}

\begin{tabular}{|c|c|c|c|c|c|c|}
\hline \multirow[t]{4}{*}{ Domain } & \multirow[t]{4}{*}{ Item } & \multicolumn{3}{|l|}{ Score Value } & \multirow{4}{*}{$\begin{array}{l}\text { Response } \\
\text { Ranking }\end{array}$} & \multirow[t]{4}{*}{ Result } \\
\hline & & \multirow{3}{*}{$\begin{array}{l}\text { Fuzzy } \\
\text { Assessment }\end{array}$} & Average & \multirow{3}{*}{$\begin{array}{l}\text { Element } \\
\text { Threshold } \\
\text { Value (D) }\end{array}$} & & \\
\hline & & & Of Fuzzy & & & \\
\hline & & & Number & & & \\
\hline \multirow[t]{8}{*}{ SMGS } & 1 & 15.200 & 0.691 & 0.197 & 1 & ACCEPT \\
\hline & 2 & 14.800 & 0.673 & 0.194 & 3 & ACCEPT \\
\hline & 3 & 14.933 & 0.682 & 0.197 & 2 & ACCEPT \\
\hline & 4 & 14.200 & 0.645 & 0.215 & 5 & REJECT \\
\hline & 5 & 13.800 & 0.6455 & 0.192 & 4 & ACCEPT \\
\hline & 6 & 13.633 & 0.6197 & 0.176 & 6 & ACCEPT \\
\hline & 7 & 13.267 & 0.6030 & 0.195 & 7 & ACCEPT \\
\hline & 8 & 15.600 & 0.5939 & 0.212 & 8 & REJECT \\
\hline Threshold & 0.197 & & & & & \\
\hline \multicolumn{7}{|l|}{ Value (d) } \\
\hline Consensus & $75 \%$ & & & & & \\
\hline $\begin{array}{l}\text { Percentage for Total } \\
\text { Items }\end{array}$ & & & & & & \\
\hline
\end{tabular}

According to the results in the above table, the experts considered the most important item for SMGS is to "develop or adopt an enrichment syllabus to meet gifted students" needs in multiple fields". As a consequence, the experts believed that gifted students are needy for an enrichment syllabus in different fields such as maths, applied sciences, and languages to address their ambitions.

However, there was no consensus on two items namely: "...the school has to either obtain or develop an enrichment syllabus in sports for gifted students" and "...the school has to either obtain or develop an enrichment syllabus in applied sciences for gifted students".

\section{Experts' Consensus on the Proposed Strategy for SDGE}

The third domain in the proposed strategy is SDGE that comprised ten items. The following table presents the items listed under this domain. 
Table: 13 Proposed Items for SDGE Domain

\begin{tabular}{|c|c|c|}
\hline No. & Item type & Items for the SDGE \\
\hline 1 & Goal & Ensure school staff are qualified in gifted education issues. \\
\hline 2 & Objective & Train the school staff in identification procedures for gifted students. \\
\hline 3 & Objective & Train the school staff in suitable pedagogies for gifted students. \\
\hline 4 & Objective & $\begin{array}{l}\text { Train the school staff on how to employ the official syllabus for gifted } \\
\text { students. }\end{array}$ \\
\hline 5 & Objective & Increase awareness among school staff of gifted students. \\
\hline 6 & Objective & Train the school staff in dealing with gifted students. \\
\hline 7 & Strategies & $\begin{array}{l}\text { Hold training workshops on ten applied strategies for teaching gifted } \\
\text { students. }\end{array}$ \\
\hline 8 & Strategies & $\begin{array}{l}\text { Hold training workshops on how to employ the official syllabus for gifted } \\
\text { students. }\end{array}$ \\
\hline 9 & Strategies & Motivate the staff members who will cater to gifted students. \\
\hline 10 & Strategies & Hold training workshops on how to deal with gifted students. \\
\hline
\end{tabular}

After obtained these items from the PPS principals, the researchers sent them to the same panel of experts for validation and getting the consensus. The following table presents the result.

Table: 14 Experts' Consensus on SDGE Items

\begin{tabular}{|c|c|c|c|c|c|c|}
\hline \multirow[t]{2}{*}{ Domain } & \multirow[t]{2}{*}{ Item } & \multicolumn{3}{|l|}{ Score Value } & \multirow{2}{*}{$\begin{array}{l}\text { Response } \\
\text { Ranking }\end{array}$} & \multirow[t]{2}{*}{ Result } \\
\hline & & $\begin{array}{l}\text { Fuzzy } \\
\text { Assessment }\end{array}$ & $\begin{array}{l}\text { Average Of } \\
\text { Fuzzy } \\
\text { Number }\end{array}$ & $\begin{array}{l}\text { Element } \\
\text { Threshold } \\
\text { Value (D) }\end{array}$ & & \\
\hline \multirow[t]{10}{*}{ SDGE } & 1 & 15.600 & 0.7091 & 0.189 & 2 & ACCEPT \\
\hline & 2 & 15.600 & 0.7091 & 0.177 & 2 & ACCEPT \\
\hline & 3 & 15.600 & 0.7091 & 0.177 & 2 & ACCEPT \\
\hline & 4 & 15.200 & 0.6909 & 0.197 & 6 & ACCEPT \\
\hline & 5 & 15.400 & 0.7000 & 0.181 & 5 & ACCEPT \\
\hline & 6 & 15.200 & 0.6909 & 0.197 & 6 & ACCEPT \\
\hline & 7 & 14.400 & 0.6545 & 0.202 & 10 & REJECT \\
\hline & 8 & 15.200 & 0.6909 & 0.197 & 6 & ACCEPT \\
\hline & 9 & 16.200 & 0.7364 & 0.141 & 1 & ACCEPT \\
\hline & 10 & 14.600 & 0.6636 & 0.246 & 9 & REJECT \\
\hline $\begin{array}{l}\text { Domain } \\
\text { Threshold } \\
\text { Value (d) }\end{array}$ & 0.193 & & & & & \\
\hline $\begin{array}{l}\text { Consensus } \\
\text { Percentage for } \\
\text { Total Items }\end{array}$ & $80 \%$ & & & & & \\
\hline
\end{tabular}


exceeds the criteria of $75 \%$. Additionally, the average Fuzzy responses were all greater than 0.5 , again fulfilling the criteria. Thus, an expert consensus was obtained for eight items. The two items were rejected and thus not considered by experts to be important strategies for staff development in gifted education were: "...hold training workshops on ten applied strategies for teaching gifted students" and "...hold training workshops on how to deal with gifted students". The most practical objectives and strategies according to the experts are, therefore "motivation of the staff, ensuring the staff are qualified in gifted education, and training staff in identification procedures and suitable pedagogies for gifted students". Additionally, the experts perceived that increasing teachers' awareness of gifted students is a significant objective as well that should be part of the strategy.

\section{Experts' Consensus on the Proposed Strategy for AGSP}

For the purpose of this study, the assessment factor was classified into two sub-domains; the first sub-domain of which is AGSP and consists of six items. Whereas, the second sub-domain is EGSS which will be discussed after presenting the results of AGSP. The following table presents the items under the AGSP to propose a strategy for developing the process of assessing gifted students' performance.

Table: 15 Proposed Items for AGSP Domain

\begin{tabular}{|c|c|c|}
\hline No. & Item type & Items for the AGSP \\
\hline 1 & Goal & $\begin{array}{l}\text { Improve a system for assessing gifted students' performance in the } \\
\text { school. }\end{array}$ \\
\hline 2 & Objective & Assign the criteria for assessing gifted students' performance. \\
\hline 3 & Objective & Provide assessment instruments to assess gifted students' performance. \\
\hline 4 & Objective & Train teachers in methods for assessing gifted students' performance. \\
\hline 5 & Strategies & $\begin{array}{l}\text { Adopt and prepare a list of criteria for assessing gifted students' } \\
\text { performance in multiple domains. }\end{array}$ \\
\hline 6 & Strategies & $\begin{array}{l}\text { Hold training workshops for teachers on the methods for assessing } \\
\text { gifted students' performance. }\end{array}$ \\
\hline
\end{tabular}

As in the previous domains, these items were then sent to the experts for validation and getting their consensus, the result of which is presented below. 
INTERNATIONAL JOURNAL OF ACADEMIC RESEARCH IN PROGRESSIVE EDUCATION AND

DEVELOPMENT

Vol. 9, No. 3, 2020, E-ISSN: $2226-6348$ @ 2020 HRMARS

Table: 16 Experts' Consensus on AGSP Items

\begin{tabular}{|c|c|c|c|c|c|c|}
\hline \multirow[t]{4}{*}{ Domain } & \multirow[t]{4}{*}{ Item } & \multicolumn{3}{|l|}{ Score Value } & \multirow{4}{*}{$\begin{array}{l}\text { Response } \\
\text { Ranking }\end{array}$} & \multirow[t]{4}{*}{ Result } \\
\hline & & Fuzzy & Average of & Element & & \\
\hline & & Assessment & Fuzzy & Threshold & & \\
\hline & & & Number & Value (D) & & \\
\hline \multirow[t]{6}{*}{ AGSP } & 1 & 16.000 & 0.736 & 0.151 & 1 & ACCEPT \\
\hline & 2 & 16.200 & 0.709 & 0.141 & 2 & ACCEPT \\
\hline & 3 & 15.600 & 0.691 & 0.164 & 3 & ACCEPT \\
\hline & 4 & 15.200 & 0.655 & 0.167 & 5 & ACCEPT \\
\hline & 5 & 14.800 & 0.655 & 0.194 & 5 & ACCEPT \\
\hline & 6 & 14.400 & 0.691 & 0.222 & 3 & REJECT \\
\hline
\end{tabular}

Domain Threshold Value 0.156

(d)

Consensus Percentage for $83 \%$

Total Items

The result in the above table shows five items were less than 0.2 , reflecting an expert consensus. Besides, the overall threshold value for the domain was 0.156 , again indicating expert agreement. The total percentage of expert agreement on the AGSP was $83 \%$ that indicates a high percentage of the agreement as does the average Fuzzy response which exceeded 0.5 for every item. The italicised threshold value exceeded 0.2 and reflects no consensus on item number 33 , "...hold training workshops for the teachers on methods for assessing gifted students' performance".

\section{Experts' Consensus on the Proposed Strategy for ASGS}

The fifth domain in the strategy and second sub-domain as a factor of assessment is ASGS that contains five items. It concerns the assessment of programmes and services for gifted students that were offered by the PPS. These items were developed also based on the focus group responses. The following table shows the proposed items for ASGS.

Table: 17 Proposed Items for ASGS Domain

\begin{tabular}{lll}
\hline No. & Item type & Items for the ASGS \\
\hline 1 & Goal & Improve a system for assessing gifted students' services in the school.
\end{tabular}

2 Objective Assign the criteria for assessing gifted students' services in the school.

3 Objective Ensure a group of teachers are qualified in the methods for assessing gifted students' services in the school.

4 Strategies Adopt and prepare a list of criteria for assessing gifted students' services in the school.

5 Strategies Provide assessment instruments for assessing gifted students' services in the school.

To ensure their usefulness for assessing the services of gifted students, these items were sent to the experts for validation. The following table presents the result of the Fuzzy Delphi analysis. 
INTERNATIONAL JOURNAL OF ACADEMIC RESEARCH IN PROGRESSIVE EDUCATION AND

DEVELOPMENT

Vol. 9, No. 3, 2020, E-ISSN: $2226-6348 @ 2020$ HRMARS

Table: 18 Experts' Consensus on ASGS Items

\begin{tabular}{|c|c|c|c|c|c|c|}
\hline \multirow[t]{3}{*}{ Domain } & \multirow[t]{3}{*}{ Item } & \multicolumn{3}{|l|}{ Score Value } & \multirow{3}{*}{$\begin{array}{l}\text { Response } \\
\text { Ranking }\end{array}$} & \multirow[t]{3}{*}{ Result } \\
\hline & & Fuzzy & Average of & Element & & \\
\hline & & Assessment & Fuzzy Number & $\begin{array}{l}\text { Threshold } \\
\text { Value (D) }\end{array}$ & & \\
\hline \multirow[t]{5}{*}{ ASGS } & 1 & 15.200 & 0.691 & 0.197 & 2 & ACCEPT \\
\hline & 2 & 14.800 & 0.673 & 0.177 & 3 & ACCEPT \\
\hline & 3 & 15.400 & 0.700 & 0.153 & 1 & ACCEPT \\
\hline & 4 & 14.700 & 0.668 & 0.204 & 4 & REJECT \\
\hline & 5 & 14.600 & 0.664 & 0.189 & 5 & ACCEPT \\
\hline Domain & \multicolumn{6}{|l|}{0.182} \\
\hline \multirow{2}{*}{\multicolumn{7}{|c|}{$\begin{array}{l}\text { Threshold } \\
\text { Value (d) }\end{array}$}} \\
\hline & & & & & & \\
\hline Consensus & $80 \%$ & & & & & \\
\hline Percentage & & & & & & \\
\hline
\end{tabular}

As reflected in the table above, five out of six items threshold values were less than 0.2 and were therefore accepted as they obtained the expert consensus. Besides, the average Fuzzy response was above 0.5 and the overall threshold value for the domain was 0.182 , again reflecting experts' agreement on the domain. Furthermore, the overall percentage of expert agreement on the ASGS was $80 \%$, which is high.

Based on the experts' views, the most feasible item is number 36 which stating "...to qualify and train a group of teachers in the methods needed to assess gifted students' services". Experts believe that offering teachers with on-going workshops will indirectly boost their confidence in assessing gifted programmes or services in the PPS. The experts believed this item can be implemented and that teachers can assess these services. Another important item is the need to develop an accurate system for assessing the services of gifted students in the schools. The third most important item is that of "assigning and determining criteria for assessing gifted students" services in the school".

\section{Experts' Consensus on the Proposed Strategy for SPGE}

The focus group results confirmed the significance of the strategic planning for developing gifted education in PPS. Based on the responses of the participants, the following eight items were proposed under the domain (SPGE). The following table depicts these items. 
Table: 19 Proposed Items for SPGE Domain

\begin{tabular}{lll}
\hline No. & Item type & Items for the SPGE \\
\hline 1 & Goal & Develop a strategic plan for gifted education in the school. \\
2 & Objective & Determine the school's vision for gifted education. \\
3 & Objective & Determine the school's mission for gifted education. \\
4 & Objective & Determine the school's goals for gifted education \\
5 & Objective & Determine the school's objectives for gifted education. \\
6 & Objective & Determine the school's strategies for gifted education. \\
7 & Strategies & The school shapes its vision for gifted education. \\
8 & Strategies & The school shapes its mission for gifted education. \\
\hline
\end{tabular}

To ensure their importance in developing gifted education in the PPS, these items were sent to the experts for validation to obtain their consensus. The following table shows the Fuzzy Delphi analysis for SPGE.

Table: 20 Experts' Consensus on SPGE Items

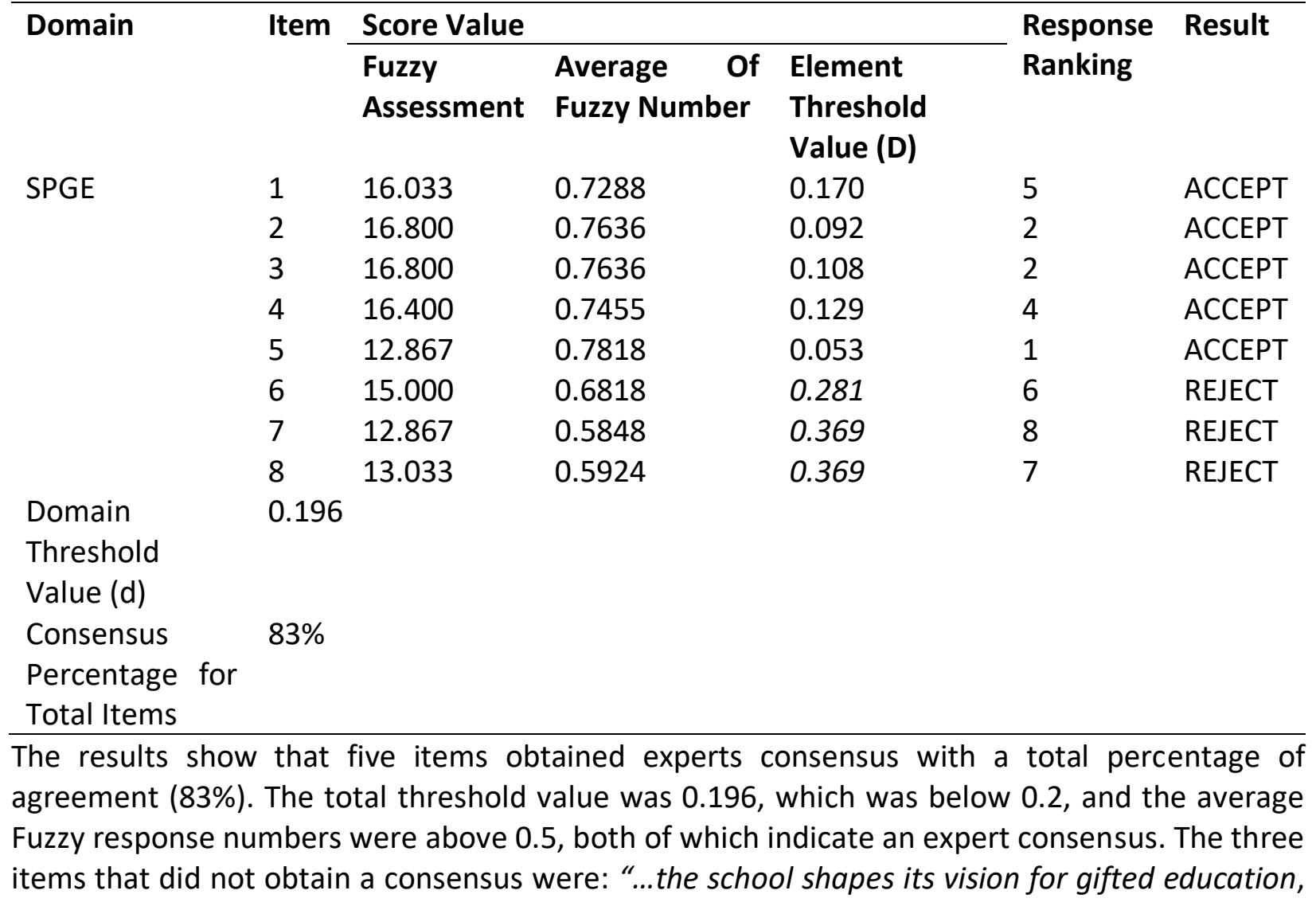




\section{INTERNATIONAL JOURNAL OF ACADEMIC RESEARCH IN PROGRESSIVE EDUCATION AND DEVELOPMENT}

Vol. 9, No. 3, 2020, E-ISSN: $2226-6348$ @ 2020 HRMARS

the school shapes its mission for gifted education, and determine the school's strategies for gifted education".

The experts thus argued that the PPS have to develop their strategic plan for implementing gifted education. Besides, they agreed on the items that required schools to develop their vision and mission as well as their goals and objectives in the field of gifted education.

\section{Experts' Consensus on Proposed Strategy for IPGE}

While running a focus group discussion to propose a strategic plan for gifted education in the PPS, the participants highlighted the importance of developing an implementation policy for gifted education. They believed that this would be fundamental input as it would offer a roadmap for implementation of the strategic plan. Therefore, based on the findings of the focus group, five items were proposed under the domain IPGE. The following table shows these items.

Table: 21 Proposed Items for IPGE Domain

\begin{tabular}{lll}
\hline No. & Item type & Items for the IPGE \\
\hline 1 & $\begin{array}{l}\text { Goal } \\
2\end{array}$ & $\begin{array}{l}\text { Develop an implementation policy for gifted education in the school. } \\
\text { Determine the regulations for gifted education to provide and } \\
\text { maintain equal opportunities. }\end{array}$ \\
3 & Objective & Assign standards for the identification of gifted students. \\
4 & Strategies & Adopt a practice policy for gifted education. \\
5 & Strategies & Adopt international standards for the identification of gifted students.
\end{tabular}

To ensure they are beneficial for a practice policy for gifted education, these items were then sent to the experts for validation to gain their consensus as well. The following table depicts the result of the Fuzzy Delphi analysis. 
INTERNATIONAL JOURNAL OF ACADEMIC RESEARCH IN PROGRESSIVE EDUCATION AND

DEVELOPMENT

Vol. 9, No. 3, 2020, E-ISSN: $2226-6348 @ 2020$ HRMARS

Table: 22 Experts' Consensus on IPGE Items

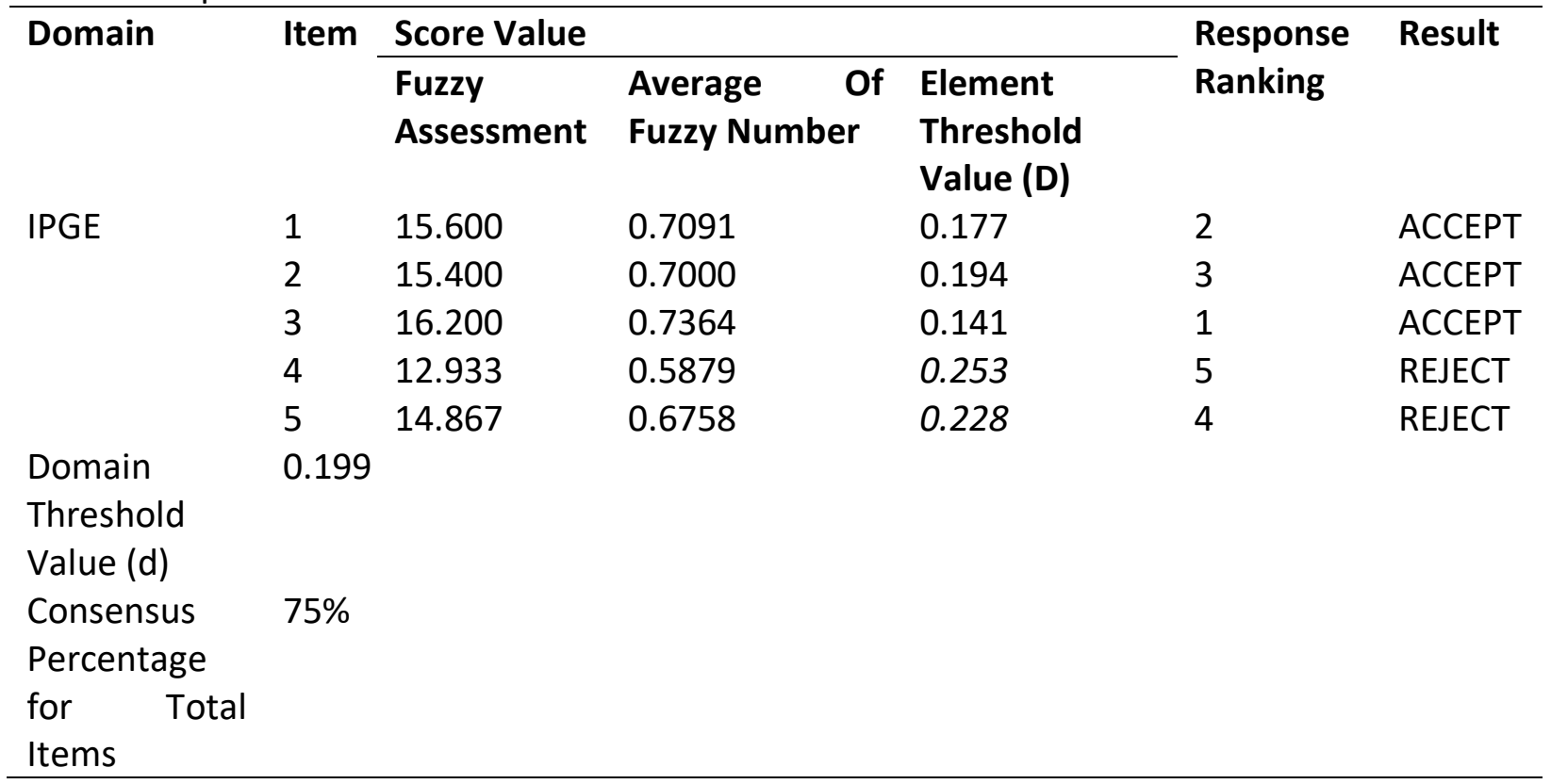

As reflected in the table number 22, the italicised threshold values of two items were greater than 0.2 , reflecting an expert consensus had not been reached. These were "...adopt a practice policy" and "...adopt international standards for the identification of gifted students". However, the total domain value (d) was less than 0.2 (0.199) reflecting an expert consensus (Cheng \& Lin, 2002) and the overall percentage of consensus was above $75 \%$. Besides, the average Fuzzy response was also more than 0.5. The experts thus believe it is important to develop an implementation policy for gifted education because it will guide the PPS in the right direction while implementing gifted education. Moreover, they believe that assigning the regulations for gifted education will offer and maintain equal opportunities. This is a direct benefit of the practice policy. Also, the practice policy should assign the standards for the identification process of gifted students.

\section{Discussion}

The identification of gifted students (IGS) is one of the most important issues in gifted education (Chan, Chan, \& Zhao, 2009). Once the gifted is recognised, it will be easier to develop his/her giftedness. However, the process of recognising the gifted is that easy and there is a consensus among educators and psychologists concerning the difficulty of recognising gifted students. This is due to the need of multiple instruments of identification and not only tests of $I Q$, the latter of which is the main criterion that has been considered and comprises intelligence tests such as the "Wechsler Intelligence Scale for Children" (WISC) (Cross, Cross, \& Finch, 2010; Veiga et al., 2014). As aforementioned, there is no approved single universal way for recognising gifted students. Therefore, the recognising process should be based on multiple methods of assessment as much as possible (Al-Makhalid, 2013; Harrison, 2004). Furthermore, no single test score precludes eligibility for provision (Brown, Avery, VanTassel-Baska, \& Worley, 2003).

As a consequence, to formulate a strategy for the PPS to develop IGS is not an easy task. The researchers, therefore, gathered data for developing IGS from qualified and experienced school 
principals. The results were then validated by sending them to experts in different fields of education. To achieve the results generated by the PPS principals were written in a form of a questionnaire to make it easier to validate them. Then the Fuzzy Delphi method was used to obtain expert consensus for every single item of IGS. The accepted percentage of consensus should be $75 \%$ or above, as reported by (Tang \& Wu, 2010). Items that do not obtain a $75 \%$ consensus are therefore rejected (Chang et al., 2011; Cheng \& Lin, 2002).

In the beginning, the researchers proposed nine items for IGS domain based on the PPS principals views. Seven out of the nine achieved an expert consensus, the most important of which will now be highlighted. The item that achieved the highest rank requires the PPS to assign standards for the identification of gifted students. This reveals awareness among the experts of the need to provide standards in order for the PPS to be able to recognise gifted students. The second-highest ranked item needs the PPS to improve specific regulation for IGS. The experts emphasised on the significance of unifying the regulation to be implemented whenever the PPS required to commence any identification campaign. The third highest ranked item stated: "determine who the gifted student is". The experts confirmed that every school from the PPS should operationally define the concept of a "gifted student". They affirmed that this will be of substantial advantage to the PPS in recognising those who are gifted. Therefore, lots of countries, ministries of education, and learning institutions all over the world have defined this concept. On the other hand, two items were rejected as the expert consensus score was greater than the threshold value of 0.2 , which reflects no consensus (Tang \& Wu, 2010). However, the overall percentage of consensus for the IGS domain was $78 \%$ which indicates good agreement on the proposed strategy (Chang et al., 2011; Cheng \& Lin, 2002).

In previous decades, syllabus materials for gifted students (SMGS) have attracted the attention of multiple educators because they think it is a new issue (VanTassel-Baska, 1986). First ideas on the requirement to provide multiple syllabus options were based on the multiple prototypes of gifted students originated by Kaplan (1982). However, it has been a long time since the initiative and ideas for a syllabus for gifted students were launched and it is still new in the context of Yemen. Several educators are wondering what happens after schools recognise gifted students? This question emerged because there is no specilsed syllabus for those gifted in multiple fields of giftedness. Once the schools recognise those who are gifted, they do not find an appropriate syllabus to improve their giftedness in different fields. Sometimes, however, it is not necessary to have a separate syllabus for gifted students; it can be developed from the official syllabus. For example, some enrichment materials can be developed by the teachers for the official syllabus. The proposal for a differentiated syllabus as a form of provision for gifted students was supported by several scholars (Tomlinson \& Reis, 2004).

To develop SMGS in the PPS, the researchers proposed eight items, six of which got an expert consensus. The item ranked number one requires the schools to develop or adopt an enrichment syllabus to address gifted students' needs. The experts emphasised that the provision of gifted students syllabus is important and thus the PPS have a duty either to develop an enrichment syllabus based on official syllabus materials or adopt a ready-made enrichment syllabus. The item ranked number two requires schools to develop an enrichment syllabus for gifted students in mathematics. The experts also believe that cognitive giftedness is significant which is why they prioritised an enrichment syllabus for mathematics as this is a subject that improves problem- 
solving as well as cognitive abilities. Indeed, cognitive abilities were the first characteristics used to identify gifted students. In the final quarter of the twentieth century, Gardner (1983) developed his theory of multiple intelligences (MI). Thus the idea of using cognitive abilities only to recognise the gifted disappeared as other abilities can be categorised as characteristics of gifted students. On the other hand, two items did not receive an expert consensus, however, the total percentage of consensus for SMGS domain was $75 \%$ which indicates a high level of agreement among experts (Chang et al., 2011; Cheng \& Lin, 2002).

Fundamentally, experts believed school staff should be trained in gifted education, particularly the teachers. However, when preparing student teachers (, the faculty of education does not provide them with enough knowledge and skills in gifted education. Besides, Neumeister and Burney (2012) discover that even experienced teachers continue to hold a narrow conception of giftedness. The authors also identified that teachers may not be aware of how environmental and cultural elements can influence the expression of giftedness in the minority and disadvantaged learners. Also, Jarwan (2005) argued that the teaching staff are ranked at the top of all elements contributing to the success of gifted programmes. Therefore, he believed that careful selection and qualifying the staff before and after service is an important issue. He also highlighted the areas that should be focused on while training the teacher, such as theoretical information about giftedness, cognitive and affective characteristics, gifted students, needs and obstacles, creative and critical thinking, characteristics and classroom climate, academic assessment for the gifted, and research and methods. The results of this study affirmed the existing literature views; all participants confirmed the significance of teachers' development in gifted education. They considered the training of teachers to be a fundamental factor in launching any programme for gifted students. Therefore, and based on their views, the researchers proposed an SDGE strategy that contained ten items. To validate these items, a group of experts in different fields of education were asked to reach a consensus on the proposed strategy. The result reflected that the total percentage of consensus for SDGE was $80 \%$, which indicates a high level of consensus on the proposed items for this domain (Chang et al., 2011; Cheng \& Lin, 2002).

In terms of the specific details, the experts ranked item number nine the highest, which needs the PPS to motivate teachers who are aware of gifted students. The experts believe that motivation is an effective factor in education not only for the students but also for the teachers. In terms of the item ranked second, three were ranked equally: a) qualify the school staff in gifted education issues; b) train the school staff in identification issues; c) train the school staff in suitable pedagogies. These indicate the significance of developing teachers' skills in gifted education. This result indicated the concerns of previous studies concerning the urgent need to train and develop teachers' knowledge and skills in gifted education issues. On the other hand, two items were rejected as their threshold value was greater than 0.2 (Tang \& Wu, 2010), the total percentage of consensus for SDGE items was $80 \%$, which indicates a high level of consensus among experts (Chang et al., 2011; Cheng \& Lin, 2002).

The assessment of giftedness is a and important strand in the education of the gifted that aims to convert potential into achievement and stimulate increased performance from students (Faulkner, 2003). Al-Salmi (2001) explained that the assessment of gifted students is a basic requirement it is a scientific process that needs qualified staff who can use the reliable and 
suitable instrument for AGSP. Therefore, there should be a strategy for AGSP. To that end, the researchers proposed a strategy that contained six items that were then showed to experts to obtain a consensus. The experts believed in the significance of the assessment process, therefore they ranked highest the item that requires PPS to improve a system for assessing gifted students' performance. The second-highest ranked item requires PPS to assign specific criteria for assessing gifted student performance. Furthermore, the experts wanted AGSP in the PPS to be based on assigned criteria in order to generate reasonable and fair results among the gifted. Besides, the experts ranked two items as the third-highest priority. The first states that schools should offer assessment instruments for AGSP while the second states the schools should hold training workshops for teachers on the methods for assessing gifted students' performance. This reflects that the experts are concerned with AGSP instruments and the criteria that will be used to measure this. Furthermore, the results indicate that experts are concerned with training teachers on how to assess gifted performance. To sum up, the total percentage of consensus was $83 \%$, which reflects a very high level of consensus (Chang et al., 2011; Cheng \& Lin, 2002). However, one item was rejected as its threshold value was greater than 0.2 (Tang \& Wu, 2010). On the other hand, the assessment of gifted students services (ASGS) also is a fundamental factor in developing services and programmes for the gifted. To develop ASGS, the researcher proposed a strategy containing five items that were then sent to a panel of experts to generate a consensus. The result reflects that the total percentage of an expert consensus for ASGS domain was $80 \%$, which indicates a high level of consensus. However, one item was rejected because its threshold value was greater than 0.2 , the overall consensus for ASGS was $80 \%$, which is extremely high (Chang et al., 2011; Cheng \& Lin, 2002).

The results of this study found that there is a lack of strategic planning for gifted education (SPGE) in PPS in Hadhramout governorate. Therefore, eight items were proposed to develop SPGE in the PPS. These items were then sent to a panel of experts in education and administration to generating a consensus. The item ranked highest by experts requires schools to determine their objectives for gifted education. The experts believed that setting the objectives of any work conducted will enable teachers to know exactly they are doing and why they are doing it. Therefore, experts wanted the schools to be aware of their objectives and why they should cater for gifted students. Two items were ranked second; the first requires schools to determine their vision for gifted education and the second requires schools to set their mission for gifted education. However, three items were rejected as their threshold values were greater than 0.2 (Tang \& Wu, 2010). However, the overall level of consensus for SPGE was $83 \%$, which indicates an extremely high agreement among experts (Chang et al., 2011; Cheng \& Lin, 2002).

Once PPS has formulated a strategic plan to develop gifted education, they need to implement that plan to achieve the desired change. And due to the change theory that involves three phases: initiation, implementation, and institutionalisation. The three phases are inter-related as they all lead to the same outcomes (Fullan, 2007). The implementation of the strategic plan requires a policy to lead that implementation. As VanTassel-Baska (2009b) reported, at a state level, gifted educational policy is tied to the rules and regulations adopted by state legislatures that govern the administration of programmes and control how funding is allocated. Similarly, for this study, the views of participants reflected the significance of developing an implementation policy for gifted education in private basic education schools to run the programmes. An IPGE strategy was 
therefore proposed to lead schools in developing their practice policy. The proposed IPGE comprised five items. The experts ranked highest the item that requires schools to assign standards for the identification of gifted students. The experts believed that the criteria for identifying the gifted are an important factor that should be stated clearly in the policy for gifted education. Previous studies have confirmed that clear criteria will benefit the schools in identifying those who are gifted (Mammadov, 2015; VanTassel-Baska, 2009b; Warne \& Price, 2016). The item ranked second requires schools to develop an implementation policy for gifted education while the item ranked third requires schools to determine the regulations for gifted education to maintain justness and equity in the provision of equal opportunities. This item was mentioned in previous studies as one of the advantages of the policy for gifted education. The total percentage of consensus for IPGE was $75 \%$, which indicates a high level of consensus (Chang et al., 2011; Cheng \& Lin, 2002). However, two items were rejected because their threshold value was greater than 0.2 (Tang \& Wu, 2010).

\section{Conclusion}

The current study's major findings include the development and expert validation of a gifted education strategic plan for PPS in Hadhramout governorate. The developed strategy obtained experts consensus in all domains. It consisted of seven domains with a total of 51 items. The first domain is IGS, which covers nine items. The item ranked the most important is "Assign the standards for the identification of gifted students". This result could be because the experts see the importance of identifying gifted students. The item ranked the least important out of the nine items is "The school has to train a specific committee for identifying gifted students".

The second domain is SMGS which covers eight items. The item ranked number 1 is "develop or adopt an enrichment syllabus to meet gifted students' needs in different fields". The availability of enrichment syllabus for a gifted student is crucial. Hence, the experts ranked this item in SMGS as ranked number one. Meanwhile, the item that came in the last is "the schools have to either obtain or develop an enrichment syllabus in sports for gifted students". The third domain is SDGE covers ten items. The item ranked number 1 as the most important is "motivate the staff members who will cater to gifted students". In this light, motivation is a significant element in education for both young people and adults. Hence, the item on motivating the staff members was ranked first out of the ten items of SDGE. The item with the lowest rank is "hold training workshops on ten applied strategies for teaching gifted students".

The fourth domain is AGSP with 6 items. The item ranked number 1 is "improve a system for assessing gifted students' performance in the school". The next domain is ASGS which covers 5 items. The item ranked number 1 is "ensure a group of teachers are qualified in the methods of assessing gifted students'services". The sixth domain is SPGE which covers 8 items and the item that ranked first is "determine the school objectives for gifted education". This indicates that setting the objectives for gifted programmes will guide schools to implement these programmes effectively. The item ranked last is "the school shape its vision for gifted education". This reflects that the experts believe that the gifted education programme's aim and vision should be shaped by the Ministry of education. The final domain is IPGE which covers five items. The item ranked first is "assign standards for identification of gifted students". In contrast, the item ranked the last one is "adopt a practice policy for gifted education". 
As mentioned, this study aimed to develop a strategic plan for developing gifted education in PPS. The first national programme for gifted students was launched in Yemen in 2005 in a sample of public schools in three out of 21 governorates. This study was, therefore, conducted to assess whether the needs of the many gifted students attending private schools are addressed or not. The implementation of gifted education in PPS is surrounded by several complexities, such as training school staff, obtaining identification instruments, developing enrichment curriculums, obtaining evaluation instruments, and determining an approach for gifted education to be followed by schools. Therefore, this study developed a strategic plan to develop gifted education in PPS to overcome these obstacles. Furthermore, during the implementation of the developed strategic plan, any emerging issues will need to be tackled to enhance gifted education in PPS.

\section{Recommendations}

The PPS needs to undergo a comprehensive transformation to meet the ambitious vision and aspirations of gifted students. Therefore, a collaboration between all PPS stakeholders is highly recommended to ensure gifted education programme's success by implementing the developed strategic plan. Other recommendations are as follow,

First, gifted students are mostly deemed as the nation's intellectual capital at the international level (Şahin, 2015). First and foremost, the PPS need to support gifted students; for example, these schools need to provide gifted programmes for their students to meet their needs and ambitions.

Second, the PPS have to train their teachers in gifted education issues. In this light, teachers are the heart of the educational process (Bin Suliman, 2020). Therefore, PPS could not develop gifted education unless they ensure that their teachers are familiar with all aspects of gifted education (Jarwan, 2005).

Third, PPS should obtain standardised instruments for the identification of gifted students. They should also train teachers on how to use these instruments. Fourth, PPS should improve or design enrichment syllabuses for gifted students as these are fundamental in supporting their cognitive development. Fifth, the assessment process plays an important role in assessing the performance of gifted students' performance and progress. Therefore, schools should improve their assessment instruments and procedures. Finally, this study developed a strategic plan based on expert consensus. The plan provides a valuable opportunity for PPS to develop gifted education to fulfil the needs and aspiration of gifted students.

\section{References}

Al-Salmi, F. A. (2001). Towards a Strategy for Developing the Gifted Child in the Kindergraten Stage in the Saudi Comunity Gulf Kids, 444-465.

Al-Makhalid, K. (2013). Primary Teachers Attitudes and Knowledge Regarding Gifted Pupils and Their Education in the Kingdom of Saudi Arabia (Doctoral dissertation). In: University of Manchester, UK/online/. Retrieved on 4th January.

Alfred, R. L. (2006). Managing the big picture in colleges and universities: From tactics to strategy: Greenwood Publishing Group.

Ambrosi, M. (2010). Development of a strategic planning model for automotive supplier. University of Surrey (United Kingdom), 
INTERNATIONAL JOURNAL OF ACADEMIC RESEARCH IN PROGRESSIVE EDUCATION AND

DEVELOPMENT

Vol. 9, No. 3, 2020, E-ISSN: $2226-6348 @ 2020$ HRMARS

Bin Suliman, A. (2020). Exploring the Feasibility of the Dual Language Program (DLP) Implementation in Malaysian Secondary Schools. (PhD PhD), UKM,

Brown, E. F., Avery, L. D., VanTassel-Baska, J., \& Worley, B. (2003). Gifted Policy Analysis Study for the Ohio Department of Education: Final Report: Center for Gifted Education.

Chan, D. W., Chan, L.-k., \& Zhao, Y. (2009). Twenty-five years of gifted education research in Hong Kong 1984-2008: What lessons have we learned. Educational Research Journal, 24(1), 135-164.

Chang, P.-L., Hsu, C.-W., \& Chang, P.-C. J. I. J. o. H. E. (2011). Fuzzy Delphi method for evaluating hydrogen production technologies. 36(21), 14172-14179.

Chen, C.-T. J. F. s., \& systems. (2000). Extensions of the TOPSIS for group decision-making under fuzzy environment. 114(1), 1-9.

Cheng, C.-H., \& Lin, Y. J. E. j. o. o. r. (2002). Evaluating the best main battle tank using fuzzy decision theory with linguistic criteria evaluation. 142(1), 174-186.

Chu, H.-C., \& Hwang, G.-J. J. E. s. w. a. (2008). A Delphi-based approach to developing expert systems with the cooperation of multiple experts. 34(4), 2826-2840.

Cross, J. R., Cross, T. L., \& Finch, H. (2010). Maximizing student potential versus building community: An exploration of right-wing authoritarianism, social dominance orientation, and preferred practice among supporters of gifted education. Roeper Review, 32(4), 235248.

Darwish, S., Alzayed, S., \& Ahmed, U. (2020). How Women in Science can Boost Women's Entrepreneurship: Review and Highlights. International Journal of Innovation Creativity and Change, 14(1), 453-470.

Faulkner, H. (2003). Predicting gifted foreign language learning and performance. University of Nottingham,

Fullan, M. (2007). The new meaning of educational change: Routledge.

Gardner, H. (1983). Frames of mind: The theory of multiple intelligences. New York: Basic Books. (New editions 1993, 2004).

Harrison, C. (2004). Giftedness in early childhood: The search for complexity and connection. Roeper Review, 26(2), 78-84.

Jarwan, F. A. (2005). Schools and Academies for Gifted Students Project: General Framework Project Frameork. Retrieved from http://www.jarwan-center.com/main/wpcontent/uploads/2013/04/Schools_Academies_of_the_Gifted_in_Yemen.pdf

Johnson, B., \& Christensen, L. (2008). Educational research: Quantitative, qualitative, and mixed approaches: Sage.

Kaonde, P. D. F. (2014). Improving strategy formulation and implementation in Higher Education institutions in Malawi: an empirical study. University of Bolton,

Kaplan, S. N. (1982). Myth: There is a single curriculum for the giftedp Response. Gifted Child Quarterly.

Mammadov, S. (2015). Current Policies and Policy Efforts for the Education of Gifted Children in Turkey. Roeper Review, 37(3), 139-149.

Merriam, S. B., \& Tisdell, E. J. (2015). Qualitative research: A guide to design and implementation: John Wiley \& Sons. 
Mittenthal, R. A. (2002). Ten keys to successful strategic planning for nonprofit and foundation leaders. TCC group, 7.

Mohamad, S. N. A., Embi, M. A., \& Nordin, N. J. I. E. S. (2015). Determining e-Portfolio Elements in Learning Process Using Fuzzy Delphi Analysis. 8(9), 171-176.

Murry Jr, J. W., \& Hammons, J. O. J. T. r. o. h. e. (1995). Delphi: A versatile methodology for conducting qualitative research. 18(4), 423-436.

Neumeister, K. S., \& Burney, V. H. (2012). Gifted Program Evaluation: ERIC.

Plucker, J. A., \& Barab, S. A. (2005). The importance of contexts in theories of giftedness. Conceptions of giftedness, 201-216.

Porter, M. E. (2008). Competitive strategy: Techniques for analyzing industries and competitors: Simon and Schuster.

Şahin, F. (2015). Educational programs, services and support for gifted students in Turkey.

Tang, C.-W., \& Wu, C.-T. J. H. E. (2010). Obtaining a picture of undergraduate education quality: a voice from inside the university. 60(3), 269-286.

Tomlinson, C. A., \& Reis, S. M. (2004). Differentiation for gifted and talented students: Corwin Press.

VanTassel-Baska, J. (1986). Effective curriculum and instructional models for talented students. Gifted Child Quarterly, 30(4), 164-169.

VanTassel-Baska, J. (2009a). United States policy development in gifted education: A patchwork quilt. International handbook on giftedness, 1295-1312.

VanTassel-Baska, J. (2009b). United States policy development in gifted education: A patchwork quilt. In International handbook on giftedness (pp. 1295-1312): Springer.

Veiga, F., Reeve, J., Bahia, S., Galvão, D., Tagarro, M., \& Dal-Forno, L. (2014). Students Engagement in School, Giftedness and Creativity: A literature review. Paper presented at the I Congresso Internacional Envolvimento dos Alunos na Escola: Perspetivas da Psicologia e Educação.

Warne, R. T., \& Price, C. J. (2016). A Single Case Study of the Impact of Policy Changes on Identification for Gifted Programs. Journal for the Education of the Gifted, 39(1), 49-61.

Yikici, B., Altinay, F. J. Q., \& Quantity. (2018). The importance of strategic planning and humanpower in school development. 52(1), 509-520. 